Edition KWV 
Die „Edition KWV“ beinhaltet hochwertige Werke aus dem Bereich der Wirtschaftswissenschaften. Alle Werke in der Reihe erschienen ursprünglich im Kölner Wissenschaftsverlag, dessen Programm Springer Gabler 2018 übernommen hat.

Weitere Bände in der Reihe http://www.springer.com/series/16033 
Andreas B. Günther

\section{Entrepreneurial Strategies of Professional Service Firms}

An Analysis of Commercial Law Firm Spin-offs in Germany

Springer Gabler 
Andreas B. Günther

Wiesbaden, Germany

Bis 2018 erschien der Titel im Kölner Wissenschaftsverlag, Köln

Dissertation Leuphana Universität Lüneburg, 2012

\section{Edition KWV}

ISBN 978-3-658-24090-5 ISBN 978-3-658-24091-2 (eBook)

https://doi.org/10.1007/978-3-658-24091-2

Library of Congress Control Number: 2019933864

\section{Springer Gabler}

(C) Springer Fachmedien Wiesbaden GmbH, part of Springer Nature 2012, Reprint 2019

Originally published by Kölner Wissenschaftsverlag, Köln, 2012

This work is subject to copyright. All rights are reserved by the Publisher, whether the whole or part of the material is concerned, specifically the rights of translation, reprinting, reuse of illustrations, recitation, broadcasting, reproduction on microfilms or in any other physical way, and transmission or information storage and retrieval, electronic adaptation, computer software, or by similar or dissimilar methodology now known or hereafter developed.

The use of general descriptive names, registered names, trademarks, service marks, etc. in this publication does not imply, even in the absence of a specific statement, that such names are exempt from the relevant protective laws and regulations and therefore free for general use.

The publisher, the authors and the editors are safe to assume that the advice and information in this book are believed to be true and accurate at the date of publication. Neither the publisher nor the authors or the editors give a warranty, express or implied, with respect to the material contained herein or for any errors or omissions that may have been made. The publisher remains neutral with regard to jurisdictional claims in published maps and institutional affiliations.

This Springer Gabler imprint is published by the registered company Springer Fachmedien Wiesbaden GmbH part of Springer Nature

The registered company address is: Abraham-Lincoln-Str. 46, 65189 Wiesbaden, Germany 


\section{Acknowledgements}

Conducting this extensive study would have not been possible without the support of various persons during the last years.

For this reason, I would like to thank the participating law firm spin-offs, and in particular their Partners, for agreeing to support my research project and for sharing the manifold experiences and valuable insights they had gained during the initial years of their spin-offs. For me it was a great pleasure to get to know each individual team member and to listen to their professional and personal stories. I am highly grateful for the time they spent telling me about everything from the little details to the broader context of their work. They were the critical sources for this study and helped me to understand in depth the dynamics of the spin-off market segment.

In addition, I would like to thank the market experts whom I consulted for this study. I greatly appreciate the time they invested to answer my questions. Especially in the beginning, their help gave me a big head start in my research project by making referrals, pointing out critical aspects and helping me to quickly understand the particularities of the market for legal services in general.

Beyond the persons who helped me to gather the essential field data, I am highly grateful to my supervisor, Prof. Dr. Markus Reihlen, for his continuous support throughout this study. His constructive and professional feedback was a great help throughout the research process. In taking my research forward, he always found the right balance between demanding further analyses - which in the end significantly improved the overall study - and accepting pragmatic solutions when only marginal additional insights could be expected. I specifically appreciate that he did not only support me professionally, but that he integrated me - despite me being an external researcher - in his team at his university chair. In this way it was possible to connect also personally beyond the academic work.

Moreover, I want to thank my co-supervisors Prof. Dr. Reinhard Schulte and Apl.-Prof. Dr. Ullrich Wegner for giving cross-disciplinary input, for taking the time to evaluate my study and for the interesting and challenging discussion during the thesis defense.

I would also very much like to thank my fellow students, colleagues, friends and family for their support and the invaluable intellectual exchange during my 
research project. They made the research period highly enjoyable and they were the ones who kept up my motivation during the less enjoyable phases.

Last but not least, I am thankful for the financial support of my employer, Bain \& Company, without which my research project would not have been possible.

Andreas B. Günther 


\section{Editor's foreword}

Professional services belong to the fastest growing industries in modern economies. However, our systematic understanding of the processes underlying the exploration and exploitation of new business opportunities in this sector is limited and sporadic. One reason why the two fields of professional services and entrepreneurship have operated in isolation rather than in mutual interaction are inherent contradictions between the very ideas of entrepreneurship and professionalism. The former stressing the autonomy of the free-willed entrepreneur, the latter emphasizing the internalization of and adherence to professional standards of conduct that limit creative deconstructions in professional service industries. Furthermore, the particular challenges in managing the foundation and early growth of start-up firms in the PSF sector have gained limited attention as well.

Andreas Günther's doctoral thesis on entrepreneurial strategies of professional service firms moves us into this rather novel field of research. The key question he raises is how do we understand entrepreneurial strategies of professional service firms. As a context of investigation he selected the case of commercial law firm spin-offs. The commercial law market changed rather radical since the German Supreme Court allowed the establishment of 'supra-local partnerships'. International law firms like Freshfields, Clifford Chance, Linklaters and others moved into the German market and became central actors with a significant and powerful market position. These new global players manage their operations across borders and offer an 'effortless experience' (Segal-Horn and Dean 2009) for their multinational clients. Interestingly, these international law firms are not only experts for complex legal issues, but also became entrepreneurial growth machines in exploring new business opportunities and expanding into new market niches. On the contrary, the typical German law firms are rather perceived 'as technical specialists and advisors within the constraints of a predominantly state-regulated profession, rarely engaging in legal entrepreneurialism' (Osiel 1990, pp. 20522053). Corporate lawyers trained under the governance regime of these global Anglo-Saxon law firms developed particular commercial skills useful for legal entrepreneurship. It is therefore not surprising that some former employees and partners of these global law firms started their own successful legal partnership practice. Still, little research has been conducted to explore particular challenges of managing start-up firms in the context of professional services. 
Following a grounded theory methodology Andreas' work investigates two unique cases of German commercial law firm spin-offs and addresses the foundation and early expansion of these firms. By outlining the multidimensionality of entrepreneurial strategies of professional service firms, Andreas' thesis provides a more nuanced view on start-up management and offers new avenues to overcome long existing boundaries between different research streams and perspectives. The result sheds light on a number of hitherto underexplored issues. His work will be an important stepping stone and pound of ideas for scholars interested in challenges of start-up management of professional service firms and practitioners who deal with the wickedness of daily survival. As editor of this series I wish this thesis a very positive reception from academics and practitioners alike.

\section{Markus Reihlen}

Professor of Strategic Management, Leuphana University of Lüneburg

Editor of the Advanced Management Studies Series

\section{References}

Osiel, M. J. (1990). Lawyers as monopolists, aristocrats, and entrepreneurs. Harvard Law Review, 103(8), 2009-2066.

Segal-Horn, S. and Dean, A. (2009). Delivering 'effortless experience' across borders: managing internal consistency in professional service firms. Journal of World Business, 44(1), 41-50. 


\section{Contents}

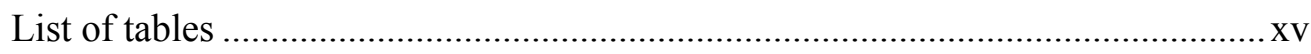

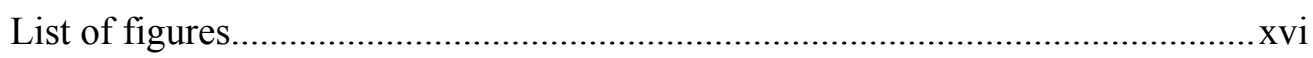

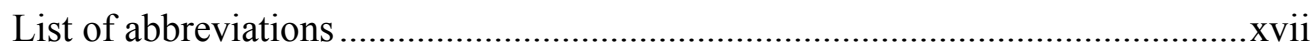

A. INTRODUCTION ........................................................................ 1

B. RESEARCH FIELD AND FOCUS ......................................................... 7

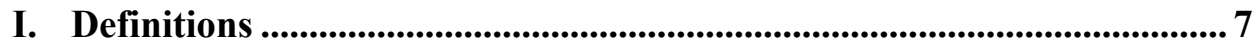

1. Definition of 'entrepreneurship' .......................................................... 7

2. Definition of 'strategy' .......................................................................... 10

3. Definition of 'professional service firm' ........................................... 12

II. Review of existing literature.............................................................17

1. Literature on entrepreneurial strategies................................................ 17

2. Literature on strategies of PSFs ......................................................... 23

3. Literature on entrepreneurial strategies of PSFs .................................. 31

III.Development of research framework ...................................................35

C. METHODOLOGICAL BACKGROUND AND RESEARCH DESIGN ........ 45

I. Introduction to qualitative research.........................................................45

1. Quantitative research vs. qualitative research..................................... 45

2. Arguments for a qualitative approach.................................................4 47

3. The nature of qualitative research...................................................... 48

3.1 Characteristics of qualitative research..................................... 48

3.2 Data collection techniques of qualitative research ....................... 49

3.2.1 Verbal techniques......................................................... 50

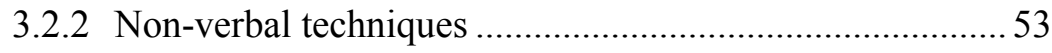

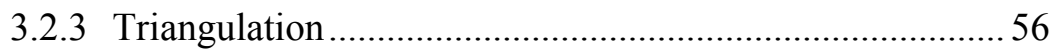

4. Key considerations for thorough qualitative research .........................5 57

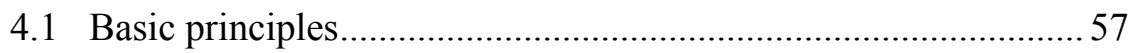

4.2 Evaluating qualitative research................................................ 58

4.2.1 Classical criteria: Reliability and validity ........................5 58

4.2.2 Alternative criteria: Trustworthiness and authenticity ...... 61 
II. Qualitative research approaches ..................................................................... 64

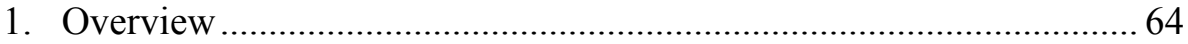

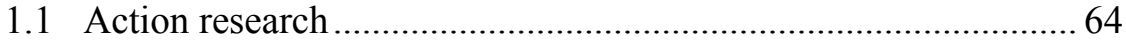

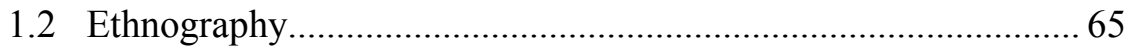

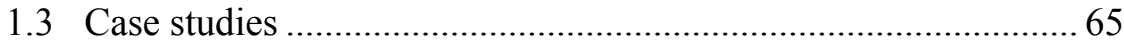

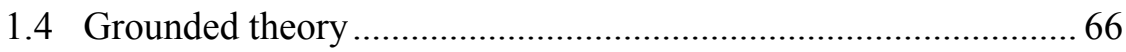

2. Detailed illustration of the case study approach ...................................67 67

2.1 Definition of and perspectives on case study research..................67 67

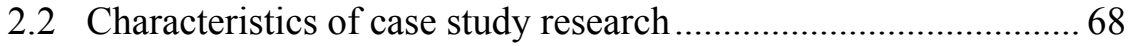

2.3 Applicability of case study research............................................. 69

2.4 Limitations and evaluation of case study research.........................69 69

2.5 Process of building theory from case study research ................... 71

2.5.1 Getting started ........................................................... 71

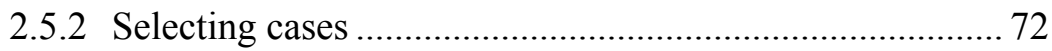

2.5.3 Crafting instruments and protocols.................................... 74

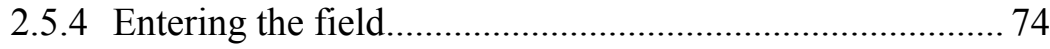

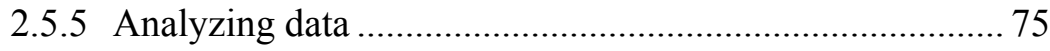

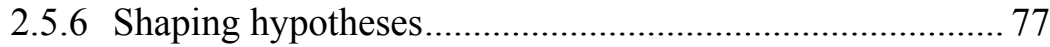

2.5.7 Enfolding literature ....................................................... 77

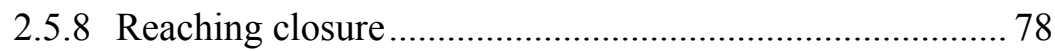

3. Detailed illustration of the grounded theory approach ......................... 78

3.1 Definition of and perspectives on grounded theory research....... 78

3.2 Characteristics of grounded theory research ............................... 82

3.3 Applicability of grounded theory research................................. 87

3.4 Limitations and evaluation of grounded theory research ............. 88

3.5 Process of data evaluation and theory development with

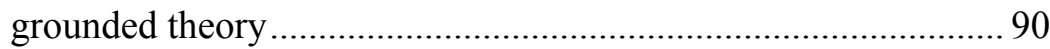

3.5.1 Theoretical sampling and saturation ................................. 90

3.5.2 Microanalysis............................................................. 91

3.5.3 Analytical tools, memos and diagrams ............................. 91

3.5.4 Definition of codes, concepts and categories ................... 96

3.5.5 Coding and conceptualizing data..................................... 97

3.5.6 Developing and refining theory ...................................... 102

3.6 Usage of computer software as supporting tool ......................... 104 
III. Research design .................................................................................. 105

1. Selection of cases and initial contact .................................................... 105

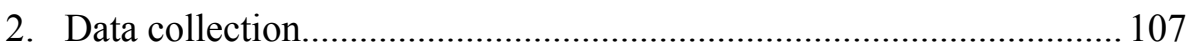

3. Data analysis and theory development............................................... 109

4. Evaluation of the research quality...................................................... 114

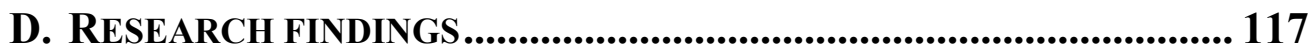

I. Industry context................................................................................................... 118

1. The market for legal services in Germany ......................................... 118

2. The commercial law market.............................................................. 122

3. Future trends and developments ..................................................... 134

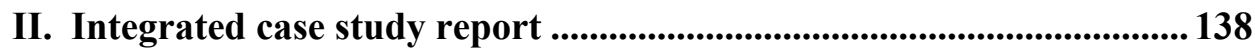

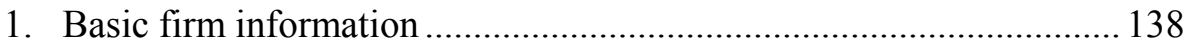

1.1 Firm A - Associate spin-off .................................................. 138

1.2 Firm P - Partner spin-off.................................................. 138

2. Guiding strategy - Firm orientation - Founding phase ..................... 139

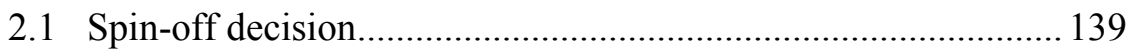

2.2 Domain choice

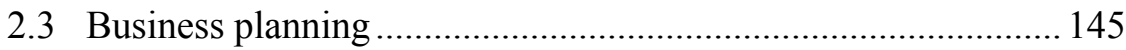

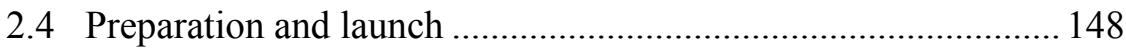

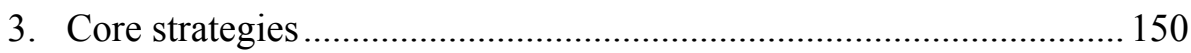

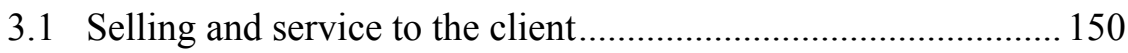

3.1.1 Acquisition .............................................................. 150

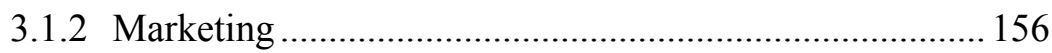

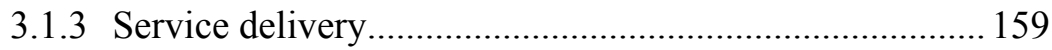

3.1.4 Pricing and billing ....................................................... 164

3.2 Winning and developing the individual ................................... 166

3.2.1 Recruiting and retention................................................. 166

3.2.2 Training and individual development ............................ 173

3.2.3 Remuneration, review process, and promotion ............... 177

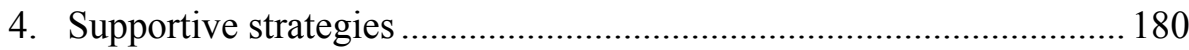

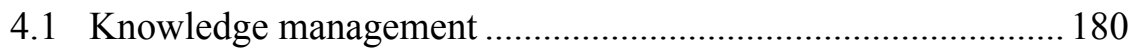

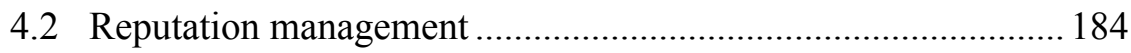




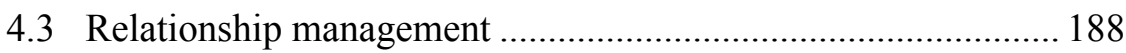

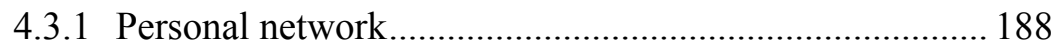

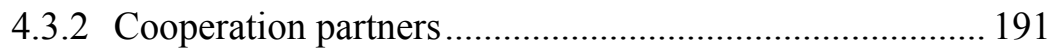

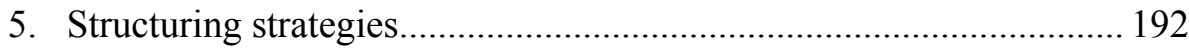

5.1 Firm leadership ................................................................ 192

5.1.1 Hierarchies, leverage and responsibilities ...................... 192

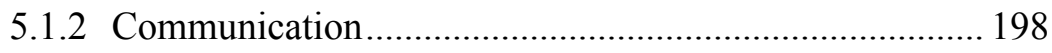

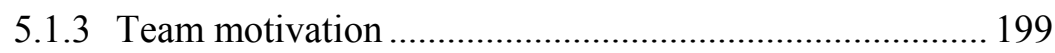

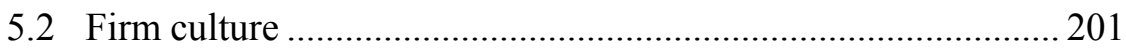

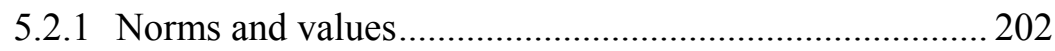

5.2.2 Full team alignment ..................................................... 205

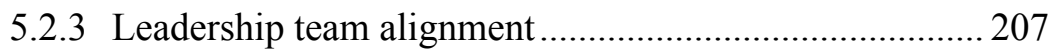

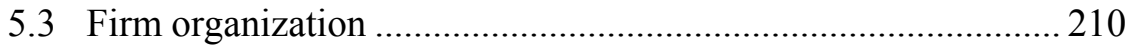

5.3.1 Processes and guidelines................................................ 210

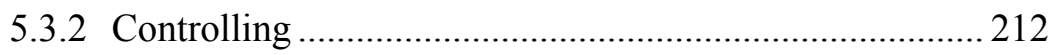

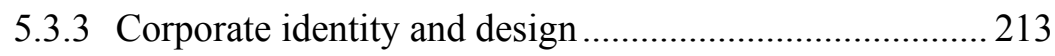

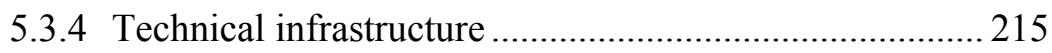

5.3.5 Back-office................................................................ 215

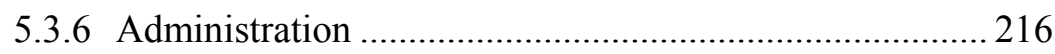

6. Guiding strategy - Firm orientation - Growth phase ........................ 217

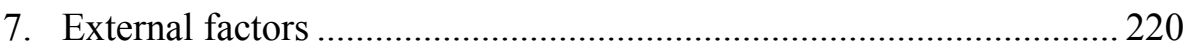

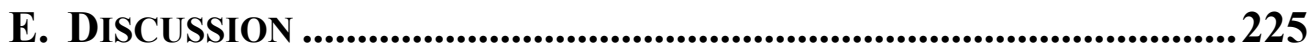

I. Conceptualization of entrepreneurial strategies and practical implications................................................................................ 225

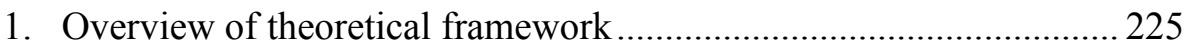

2. Detailed illustration of theoretical framework..................................... 228

2.1 Pivotal strategies of commercial law firm spin-offs .................. 228

2.1.1 Indispensable - High involvement service delivery ........ 228

2.1.2 Indispensable - Distinct people development ................. 232

2.1.3 Differentiating - Indirect client acquisition.................... 237

2.1.4 Differentiating - Strong cultural alignment.................... 243

2.2 Stabilizing strategies of commercial law firm spin-offs ............ 247

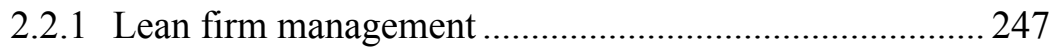

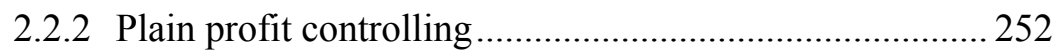

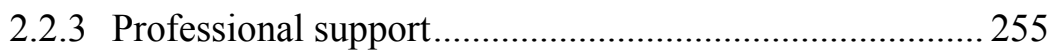


3. Cross-links between entrepreneurial strategies................................... 259

4. Summary of key findings ................................................................. 264

II. Comparison of findings with existing literature.................................. 268

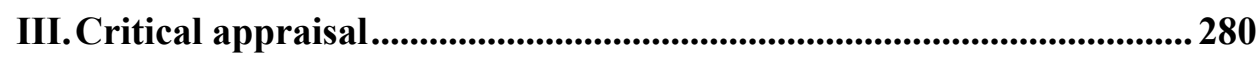

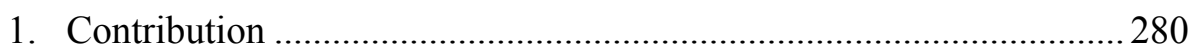

2. Limitations and suggestions for further research.............................. 281

3. Delineation of initial hypotheses for empirical theory-testing ........... 284

F. SUMMARY AND OUTLOOK........................................................... 287

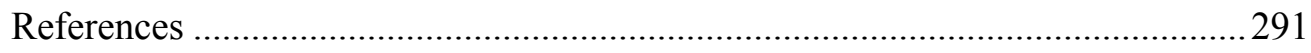




\section{List of tables}

Table 1: Overview of collected primary and secondary data ............................ 110

Table 2: Selected specialized commercial law firm spin-offs since 2000 ......... 132

Table 3: Practical implications - High involvement service delivery ............... 232

Table 4: Practical implications - Distinct people development.......................... 237

Table 5: Practical implications - Indirect client acquisition ............................. 242

Table 6: Practical implications - Strong cultural alignment .............................. 247

Table 7: Practical implications - Lean firm management................................... 251

Table 8: Practical implications - Plain profit controlling ................................... 255

Table 9: Practical implications - Professional support ..................................... 259

Table 10: Detailed overview of entrepreneurial strategies and sub-strategies..... 265 


\section{List of figures}

Figure 1: Research framework

Figure 2: Total number of certified German lawyers split by specialization (2000 vs. 2011)

Figure 3: Comparison of number of law firms, persons and related revenues (2005)

Figure 4: Total market split based on top 70 commercial law firms in Germany (2009)

Figure 5: Theoretical framework of entrepreneurial strategies 226 


\section{List of abbreviations}

$\begin{array}{ll}\text { firm A } & \text { - Associate spin-off } \\ \text { firm P } & \text { - Partner spin-off } \\ \text { CEO } & \text { - chief executive officer } \\ \text { cf. } & \text { - confer } \\ \text { CI } & \text { - corporate identity } \\ \text { CV } & \text { - curriculum vitae } \\ \text { e.g. } & \text { - for example } \\ \text { et al. } & \text { - and others } \\ \text { HR } & \text { - human resources } \\ \text { IP } & \text { - intellectual property } \\ \text { IT } & \text { - information technology } \\ \text { i.e. } & \text { - that is } \\ \text { K } & \text { - thousand } \\ \text { LLP } & \text { - limited liability partnership } \\ \text { min. } & \text { - minutes } \\ \text { n/a } & \text { - not applicable } \\ \text { p. / pp. } & \text { - page / pages } \\ \text { PSF } & \text { - professional service firm } \\ \text { R\&D } & \text { - research and development } \\ \text { UK } & \text { - United Kingdom } \\ \text { US } & \text { - United States } \\ & \end{array}$

